\title{
A rapid monitoring method for inorganic arsenic in rice flour using reversed phase-high performance liquid chromatography-inductively coupled plasma mass spectrometry
}

\author{
Tomohiro Narukawa, ${ }^{{ }_{*}{ }^{\dagger}}$ Koichi Chiba, ${ }^{b}$ Savarin Sinaviwat ${ }^{c}$ and Jörg Feldmann ${ }^{c}$ \\ ${ }^{a}$ National Metrology Institute of Japan (NMIJ), National Institute of Advanced Industrial \\ Science and Technology (AIST), 1-1-1 Umezono, Tsukuba, Ibaraki 305-8563, Japan \\ ${ }^{b}$ Department of Environmental and Applied Chemistry, School of Science and Technology, \\ Kwansei Gakuin University, 2-1 Gakuen, Sanda, Hyogo, 669-1337, Japan \\ ${ }^{c}$ Environmental Analytical Chemistry TESLA- Trace Element Speciation Laboratory, University \\ of Aberdeen, Meston Building Rm G26, Aberdeen AB24 3UE, Scotland UK
}

\begin{abstract}
A new rapid monitoring method by means of high performance liquid chromatography-inductively coupled plasma mass spectrometry (HPLC-ICP-MS) following the heat-assisted extraction was developed for measurement of total inorganic arsenic species in rice flour. $\mathrm{As}(\mathrm{III})$ and $\mathrm{As}(\mathrm{V})$ eluted at the same retention time and completely separated from organoarsenic species by an isocratic elution program on a reversed phase column. Therefore, neither ambiguous oxidation of arsenite to arsenate nor the integration of two peaks were necessary to determine directly the target analyte inorganic arsenic. Rapid injection allowed measuring 3 replicates within $6 \mathrm{~min}$ and this combined with a quantitative extraction of all arsenic species from rice flour by a 15 minute $\mathrm{HNO}_{3}-\mathrm{H}_{2} \mathrm{O}_{2}$ extraction makes this the fastest laboratory based method for inorganic arsenic in rice flour.
\end{abstract}

Keywords: Arsenic speciation; HPLC-ICP-MS; Inorganic arsenic determination; Rice flour; Risk assessment; Extraction.

* Corresponding author: Tomohiro Narukawa; E-mail: tomohiro-narukawa@aist.go.jp (T. Narukawa); Tel./Fax: +81298616889.

Highlights

- A new HPLC-ICP-MS method was developed for the rapid monitoring of inorganic As

- Inorganic As can be analyzed directly since As(III) and As(V) co-eluted

- Inorganic As can be separated from all organoarsenic compounds in rice

- Three replicates can be analyzed within 6 minutes

- Complete extraction of As species from rice flour was achieved within 15 minutes 


\section{Introduction}

Knowledge of chemical species of elements present in biological and environmental samples is important for an understanding of the toxicity, metabolism and transport properties of the elements.[1-2] Therefore, determination of specific chemical forms of elements (speciation analysis) has become an increasingly active-research field in recent years.[3] Arsenic (As) is found in various chemical species in environmental and food samples. In general, naturally occurring organoarsenic compounds are considered to be of non-toxicity, but inorganic arsenic in the form of arsenite (As(III)) or arsenate $(\mathrm{As}(\mathrm{V}))$ is a class I carcinogen.

The Codex Alimentarius Commission, which provides the guideline for allowable concentrations of toxic elements and compounds in foodstuffs, approved a tolerance level of inorganic arsenic as $0.2 \mathrm{mg} \mathrm{kg}^{-1}$ in polished rice in 2014. A tolerance level for inorganic arsenic in unpolished rice is still under discussion but rice for baby and toddler food has an even lower maximum limit for inorganic arsenic $\left(0.1 \mathrm{mg} \mathrm{kg}^{-1}\right)$.[4-6] Therefore, it is now apparent that a rapid determination of total inorganic arsenic species present in rice flour is necessary for monitoring test and/or surveillance.[6]

Prior to measurements, the arsenic species in rice flour samples are generally extracted by the techniques employing heated $\mathrm{HNO}_{3}$ solutions.[7-10] Although most analytical procedures for arsenic in any foodstuffs are composed with similar operating steps, there are some specific conditions for the determination of inorganic arsenic in rice flour samples. The Codex Alimentarius Commission recommends the analytical methods of the arsenic species in rice flour, involving extraction with diluted acids (e.g. $0.15 \mathrm{M} \mathrm{HNO}_{3}$ or 1 to $2(\mathrm{v} / \mathrm{v}) \% \mathrm{HNO}_{3}$, Extraction: $100{ }^{\circ} \mathrm{C}$ for $2 \mathrm{~h}$ ) and subsequent determination of As by HPLC-ICP-MS using a reversed phase (ODS) column.[11] On the other hand, the US Food and Drug Administration (FDA) recommends $0.28 \mathrm{M} \mathrm{HNO}_{3}$ for arsenic extraction followed by IC-ICP-MS using an anion-exchange column (IC) for the determination.[12]

An ODS column is well able to separate many arsenic species; it can separate the two inorganic arsenic species, six methylated arsenic species and four arsenosugars within 10 to 15 minutes, however the peaks of As(III) and MMA tend to be very close each other. In a similar way, the peaks of DMA and arsenobetaine (AsB) and those of trimethylarsine oxide (TMAO) and tetramethylarsonium ion (TeMA) almost overlap one another.[13-15] When a large number of measurements are carried out by using one column, the column packing is likely to deteriorate and these pairs of peaks would not be separated eventually. In addition, a complex component of eluent containing ion-pair reagents and organic contents can cause a problem at the ICP-MS interface with long-term analysis.

Each of these techniques has their own advantages and disadvantages. Anionic arsenic species can be separated by an IC column with a simple component eluent and the separation 
property depends upon the component and $\mathrm{pH}$ of the eluent.[16-22] An IC column is useful to separate arsenite $[\mathrm{As}(\mathrm{III})]$, arsenate $[\mathrm{As}(\mathrm{V})]$, monomethylarsonic acid (MMA), dimethylarsinic acid (DMA), and some arsenosugars respectively, but it cannot separate some methylated arsenic compounds under a single set of operating conditions.

The main arsenic species in agricultural samples, in particular rice flour, are As(III), As(V), MMA and DMA.[23-24] TeMA however was found in Chinese rice as well.[25] Hence, only arsenic in the forms of As(III), As(V), MMA, DMA and TeMA are of interest when rice grains are going to be analyzed.

The Codex Alimentarius Commission regulation refers to the inorganic arsenic, i.e. the sum of $\mathrm{As}(\mathrm{III})$ and $\mathrm{As}(\mathrm{V})$. Nevertheless, most monitoring test methods for inorganic arsenic in rice flour separate $\mathrm{As}(\mathrm{III})$ and $\mathrm{As}(\mathrm{V})$ and determine them individually which makes the integration of two peaks necessary for the quantification of the target analyte inorganic arsenic. Another approach is to oxidize all $\mathrm{As}(\mathrm{III})$ to $\mathrm{As}(\mathrm{V})$ and subsequently measure all inorganic arsenic as $\mathrm{As}(\mathrm{V})$ using an anion column. A peak appearing in the void where As(III) would elute means that either the cationic species TeMA is in the rice grain extract or the oxidation of As(III) was not complete. Since As(III) and TeMA elute at the same time[25], TeMA should be separated from $\mathrm{As}(\mathrm{III})$ and $\mathrm{As}(\mathrm{V})$ to avoid ambiguity and so far no method has shown to be capable for showing both species separately.

One of the most important purposes of food analyses is to ensure the food safety based on the appropriate regulations with rapidity and efficiency. Therefore, a rapid screening method with high sample throughput is required. In recent year, a screening and a rapid measurement methods for inorganic arsenic in rice flour were reported; the former was a field test kit method based on the Gutzeit methodology and the latter a fast separation-detection method using IC-ICP-MS/MS.[26-27]

In this study a rapid monitoring method of inorganic arsenic in rice flour with HPLC-ICP-MS using a reversed phase column with a simple component eluent was developed. Chromatographic conditions, in particular eluent component and $\mathrm{pH}$ were optimized to determine $\mathrm{As}(\mathrm{III})$ and $\mathrm{As}(\mathrm{V})$ at the same time, and completely separate them from other organoarsenic compounds such as DMA, MMA and TeMA.

\section{Experimental}

\subsection{Instrumentations}

An ICP-MS (7500c, Agilent, Tokyo, Japan) equipped with a Micromist nebulizer (100 $\mu \mathrm{L}$ type) and a Scott spray chamber $\left(2{ }^{\circ} \mathrm{C}\right)$ was used. Typical operating parameters for the ICP-MS were as follows: incident $\mathrm{rf}$ power was $1600 \mathrm{~W}$, outer $\mathrm{Ar}$ gas flow rate $15 \mathrm{~L} \mathrm{~min}^{-1}$, intermediate Ar gas flow rate $0.9 \mathrm{~L} \mathrm{~min}^{-1}$, carrier Ar gas flow rate $0.8 \mathrm{~L} \mathrm{~min}^{-1}$ and make-up $\mathrm{Ar}$ 
gas flow rate $0.4 \mathrm{~mL} \mathrm{~min}^{-1}$. The ICP-MS was usually operated using He as the collision cell gas $\left(3 \mathrm{~mL} \mathrm{~min}^{-1}\right)$ to reduce some polyatomic molecular interferences. An HPLC was used for separation of arsenic species. The exit of the HPLC column was directly connected to the nebulizer of the ICP-MS with PEEK tubing (HPLC-ICP-MS). The typical operation conditions and its performances are shown in Table S1.

Fifteen types of columns were investigated in the experiment (Tables S2 and S3). Five types of columns categorized in group I provided satisfactory performances for rapid monitoring of inorganic arsenic compounds, but ten other types of columns categorized in group II were unsuitable for the purpose. The columns of group I are as follows; A Shim-pack VP-C8 $\mathrm{C}_{8}$ column (hereafter referred to as the $\mathrm{C}_{8}$ : particle size of the filler $5 \mu \mathrm{m}$, ID $4.6 \mathrm{~mm} \mathrm{x}$ $250 \mathrm{~mm}$, end-capped type, Shimadzu Co., Kyoto, Japan), a CAPCELL PAK $\mathrm{C}_{18}$ MG column (hereafter referred to as the $\mathrm{C}_{18}$ : particle size of the filler $5 \mu \mathrm{m}$, ID $4.6 \mathrm{~mm} \times 250 \mathrm{~mm}$, polymer-coated type, Shiseido Co., Ltd., Tokyo, Japan), a CAPCELL PAK $\mathrm{C}_{18}$ ACR (hereafter referred to as the $\mathrm{C}_{18}$ ACR: particle size of the filler $5 \mu \mathrm{m}$, ID $4.6 \mathrm{~mm} \times 250 \mathrm{~mm}$, polymer-coated type, Shiseido), a Sunrise $\mathrm{C}_{28}$ column (hereafter referred to as the $\mathrm{C}_{28}$ : particle size of the filler $5 \mu \mathrm{m}$, ID $4.6 \mathrm{~mm}$ x $250 \mathrm{~mm}$, TMS end-capped type, ChromaNik Technologies Inc., Osaka, Japan), and a DEVELOSIL $\mathrm{C}_{30}$-UG-5 $\mathrm{C}_{30}$ column (hereafter referred to as the $\mathrm{C}_{30}$ : particle size of the filler $5 \mu \mathrm{m}$, ID $4.6 \mathrm{~mm}$ x $250 \mathrm{~mm}$, end-capped type, Nomura Chemical Co. Ltd., Aichi, Japan) were used.

The columns of group II were also tested under multiple elution conditions of eight separation modes. Details are given in the Tables S2 and S3.

A heating block system (Digi PREP, SCP Science Inc., Quebec, Canada) was used for heat assisted extraction.

\subsection{Calibration standards and reagents}

The Japan Calibration Service System (JCSS) arsenic standard solution (ca. $1000 \mathrm{mg} \mathrm{L}^{-1}$, Kanto Chemical Co., Inc., Tokyo, Japan) was used as the source of the calibration standard solution. It is produced by dissolving $\mathrm{As}_{2} \mathrm{O}_{3}$ powder into $\mathrm{HNO}_{3}$ solution and contains only As(III). It did not actually contain detectable levels of any other arsenic species including $\mathrm{As}(\mathrm{V})$ and was thus used as the As(III) source standard solution.

The certified reference materials of As(V) (NMIJ CRM 7912-a), the dimethylarsinic acid (DMA) (NMIJ CRM 7913-a) and the arsenobetaine (AsB) (NMIJ CRM 7901-a) supplied by the National Metrology Institute of Japan / National Institute of Advanced Industrial Science and Technology (NMIJ/AIST, Tsukuba, Japan) were used as source standard solutions.

Source standard solutions of the other organoarsenic species such as monomethylarsonic acid (MMA), trimethylarsine oxide (TMAO), tetramethylarsonium chloride (TeMA), and 
arsenocholine bromide (AsC) were prepared from commercially available reagents (Tri-Chemical Laboratories Inc., Yamanashi, Japan), after their purity was evaluated (moisture, elemental analysis of $\mathrm{C}, \mathrm{H}, \mathrm{O}, \mathrm{Br}$ and $\mathrm{Cl}$, and arsenic impurities). Each compound was dissolved in water to prepare an in-house standard solution containing $c a .1000 \mathrm{mg} \mathrm{As} \mathrm{kg}^{-1}$.

The acids and ammonia solutions used were of ultrapur ${ }^{\circledR}$ grade (Kanto), and the organic solvents used were of HPLC grade (Kanto). Ammonium dihydrogen phosphate and diammonium hydrogen phosphate were of ultrapure grade (Kanto). Sodium 1-butanesulfonate (Tokyo Chemical Industry Co., Ltd., Tokyo, Japan), malonic acid (Wako Pure Chemical Industries, Ltd., Osaka, Japan), and tetramethylammonium hydroxide (TMAH, Tama Chemicals Co., Ltd., Kanagawa, Japan) were obtained as indicated. Ultra-pure water was generated with a Milli Q-Labo filter (Nippon Millipore Ltd, Tokyo, Japan) and was used throughout.

\subsection{Extraction procedure for arsenic species}

Arsenic species in the rice flour samples were extracted by a heat-assisted technique using acid solvent. A portion of rice flour sample $(c a .0 .5 \mathrm{~g})$ was accurately weighed into a $10 \mathrm{~mL}$ glass tube and $2 \mathrm{~g}$ of extracting solvent were added. Four kinds of extracting solvents were used here respectively; $0.15 \mathrm{~mol} \mathrm{~L}^{-1} \mathrm{HNO}_{3}, 0.28 \mathrm{~mol} \mathrm{~L}^{-1} \mathrm{HNO}_{3}, 0.30 \mathrm{~mol} \mathrm{~L}^{-1} \mathrm{H}_{2} \mathrm{O}_{2}$ and $0.20 \mathrm{~mol}$ $\mathrm{L}^{-1} \mathrm{H}_{2} \mathrm{O}_{2}+0.10 \mathrm{~mol} \mathrm{~L}^{-1} \mathrm{HNO}_{3}$. The tube was capped and placed in a dry heating block system at $100{ }^{\circ} \mathrm{C}$ for a period from $15 \mathrm{~min}$ to $2 \mathrm{~h}$. After cooling to room temperature, $8 \mathrm{~g}$ of water was added (total liquid phase: $10 \mathrm{~g}$ ). The tube was centrifuged at $4000 \mathrm{rpm}$ for $5 \mathrm{~min}$, and then the liquid phase was then passed through a $0.45 \mu \mathrm{m}$ syringe-type polyvinylidene difluoride (PVDF) membrane filter. The filtrate was analyzed by HPLC-ICP-MS.

\subsection{Certified Reference Materials (CRMs)}

NMIJ brown rice flour CRMs (NMIJ CRM 7532-a and NMIJ CRM 7533-a) and NIST rice flour SRM (SRM 1568b) were analyzed to valid the newly developed rapid monitoring method.

\section{Results and Discussion}

\subsection{Conditions for simultaneous determination of inorganic arsenic species}

Besides the columns categorized in group I, the columns in group II were also examined with various types of eluent and at various pHs shown in supplementary material 1 . However, unsatisfactory results were obtained for simultaneous determination of inorganic arsenic species. Therefore, the following discussion is limited to the experiments carried out using the columns in group I.

For chromatographic analysis of water-soluble arsenic species, $\mathrm{pH}$ of the eluent is one of 
the most effective factors to control the separation of the compounds. The separation of As(III), As(V), MMA, DMA and TeMA using the columns of group I were investigated using the eluents containing 0.001 to $0.01 \mathrm{~mol} \mathrm{~L}^{-1} \mathrm{HNO}_{3} / 0.05 \%$ methanol. With increasing $\mathrm{HNO}_{3}$ concentration (that is, lower $\mathrm{pH}$ ), As(III), MMA, DMA and TeMA were eluted faster. The retention times of each species with the eluent of $0.01 \mathrm{~mol} \mathrm{~L}^{-1} \mathrm{HNO}_{3} / 0.05 \%$ methanol are shown in Figure 1, where the chromatography was carried out with four different types of columns. Increasing carbon chain length of the chromatographic support, the retention times of $\mathrm{As}(\mathrm{III})$ and $\mathrm{As}(\mathrm{V})$ closed in each other, and they completely matched when $\mathrm{C}_{28}$ and $\mathrm{C}_{30}$ ODS columns were used. However, when $\mathrm{HNO}_{3}$ eluent was applied, the peaks tended to broaden and peaks of inorganic arsenic overlap to that of organoarsenic species using $C_{28}$ and $C_{30}$ columns. On the other hand, $\mathrm{As}(\mathrm{III})$ and $\mathrm{As}(\mathrm{V})$ always eluted faster than the organoarsenic species regardless of the carbon chain length of the columns applied. This is not surprising since the interaction of these polar inorganic arsenic species would show less interaction with the non-polar reverse phase. Tetramethylarsonium, the only cationic species under these conditions eluted last among five compounds with the $\mathrm{C}_{8}$ column, but faster than DMA with the $\mathrm{C}_{18}, \mathrm{C}_{28}$ and $\mathrm{C}_{30}$ columns. This indicates that the $\mathrm{C}_{8}$ column may have some ion exchange properties. This suggestion is also supported by the fact that the anionic $\mathrm{As}(\mathrm{V})$ elutes before the neutral $\mathrm{As}(\mathrm{III})$. In addition, the specific surface area of filler of $\mathrm{C}_{8}$ is the biggest; therefore the retention time of the first eluting species was slightly longer. In contrast, only $\mathrm{C}_{18}$ was the polymer-coated type column, and its specific surface area of filler was the smallest in the columns; hence, the retention times of As species were faster than the other columns. However, MMA and DMA were always separated even when using any columns in the group I.

Buffers and chelating agents are effective for suppressing peak tailings.[28] A series of eluents containing 1 to $5 \mathrm{mmol} \mathrm{L}^{-1}$ of diammonium hydrogen phosphate / $0.05 \%$ methanol was tested; the $\mathrm{pH}$ of the eluents was adjusted to 2.0 with $\mathrm{HNO}_{3}$. The eluents containing diammonium hydrogen phosphate reduced the tailing of the peaks, and improved the separation capacity. However, it also made $\mathrm{As}(\mathrm{III})$ and $\mathrm{As}(\mathrm{V})$ peaks split slightly from each other using $\mathrm{C}_{28}$ and $\mathrm{C}_{30}$ columns. On the other hand, it was found that the eluent with lower $\mathrm{pH}$ was effective to elute $\mathrm{As}(\mathrm{III})$ and $\mathrm{As}(\mathrm{V})$ coincidently. The ODS columns employed here are usually used in $\mathrm{pH}$ range from 2 to 10 , because the Si-C bond of the functional group will be deteriorated at $\mathrm{pH}$ of lower than 2. Therefore, a column with high resistance to acidic conditions was likely to prove valuable for simultaneous elution of $\mathrm{As}(\mathrm{III})$ and $\mathrm{As}(\mathrm{V})$.

A polymer-coated $\mathrm{C}_{18}$ ACR column, which is stable at $\mathrm{pH}$ range of 1 to 10 , was investigated using the diammonium hydrogen phosphate buffer containing $\mathrm{HNO}_{3}(\mathrm{pH} 1.5 \sim 3.0$ ) / $0.05 \%$ methanol. Although the length of the carbon chains of chromatographic support was shorter than $\mathrm{C}_{28}$ and $\mathrm{C}_{30}$ columns, the sharp peaks were observed and the retention times of 
218 As(III) and As(V) coincided completely (Table 1), whereas the MMA, DMA and TeMA were 219 observed at the different retention times. TeMA eluted before all other possible arsenic species 220 (As(III) and $\mathrm{As}(\mathrm{V})$ and DMA, MMA) in rice grains using $\mathrm{C}_{18}$ ARC column with the 221 diammonium hydrogen phosphate buffer containing $\mathrm{HNO}_{3}(\mathrm{pH} 1.5 \sim 2.0) / 0.05 \%$ methanol. $222 \mathrm{As}(\mathrm{III})$ and $\mathrm{As}(\mathrm{V})$ were determined simultaneously as total inorganic arsenic, and the 223 organoarsenic species were separated from the inorganic arsenic. This means that there is only 224 one integration necessary which shortens the SOP and may prevent errors in the routine lab. 225 Although previous methods have detected all inorganic arsenic in one peak, but a complete oxidation of $\mathrm{As}(\mathrm{III})$ to $\mathrm{As}(\mathrm{V})$ was necessary prior to the analysis. The completeness of the oxidation could often not been checked since As(III) was co-eluting with TeMA [25]. Our new method prevents this ambiguity. In addition, the concentration of diammonium hydrogen phosphate was not critical for the chromatographic separation under the operating conditions tested here.

As an optimum experimental setups, the $\mathrm{C}_{18}$ ACR column was selected and the eluent containing $1 \mathrm{mmol} \mathrm{L}^{-1}$ diammonium hydrogen phosphate $(\mathrm{pH} 2.0) / 0.05 \%$ methanol was flowed at $0.75 \mathrm{~mL} \mathrm{~min}^{-1}$. Under these conditions, the inorganic arsenic was separated from MMA, DMA and TeMA and determined within approximately $3.5 \mathrm{~min}$.

\subsection{Monitoring time}

With the object of developing a rapid monitoring method, the flow rate of the eluent was investigated to achieve quick and effective separation of the inorganic arsenic from organic arsenic species, using a $\mathrm{C}_{18}$ ACR column (particle size $5 \mu \mathrm{m}$, ID $4.6 \mathrm{~mm} \times 250 \mathrm{~mm}$ ). The inorganic arsenic were well separated from the organoarsenic species at the flow rate range from

2410.75 to $1.0 \mathrm{~mL} \mathrm{~min}^{-1}$, although the separation capacity slightly deteriorated at the flow rate more 242 than $1.1 \mathrm{~mL} \mathrm{~min}^{-1}$, because the separation factor decrease with increasing the flow rate.

243 Therefore, taking into consideration of chromatographic resolution and measurement rapidity 244 for monitoring, the flow rate of the eluent was set at $1.0 \mathrm{~mL} \mathrm{~min}^{-1}$, and then the measurement 245 time of HPLC-ICP-MS was 3 min. Each chromatogram of As(III), As(V), MMA, DMA and 246 TeMA at a flow rate of $1.0 \mathrm{~mL} \mathrm{~min}^{-1}$ are shown in Figure S2. Since the actual separation of 247 inorganic arsenic from the other organoarsenicals takes only 1 minute with 2 minutes of void, 248 samples could be injected every minute. This was demonstrated by injecting 3 replicates of one 249 extract which was determined within 6 minutes (see Figure S3). This is a considerable improvement in analysis time. 
AsC, although MMA and DMA were major organoarsenic compounds in rice flour samples. Therefore, the chromatographic characteristics of TMAO, AsB, and AsC under the operating conditions established above were investigated. When $\mathrm{C}_{18}$ ACR column was used, AsB was eluted at the same retention time as MMA, DMA, TMAO and AsC were eluted at the same retention time as TeMA. They were clearly separated from the inorganic arsenic. As the results, the organic arsenic compounds, such as MMA, DMA, TMAO, TeMA, AsB and AsC were well separated from inorganic arsenic.

\subsection{Extraction of arsenic species from rice flour samples}

A heat assisted technique was applied to the extraction of arsenic species from rice flour samples. The extraction efficiency was investigated using the following four extraction solutions; $0.15 \mathrm{~mol} \mathrm{~L}^{-1} \mathrm{HNO}_{3}, 0.28 \mathrm{~mol} \mathrm{~L}^{-1} \mathrm{HNO}_{3}, 0.30 \mathrm{~mol} \mathrm{~L}^{-1} \mathrm{H}_{2} \mathrm{O}_{2}$, and $0.20 \mathrm{~mol} \mathrm{~L}^{-1}$ $\mathrm{H}_{2} \mathrm{O}_{2}+0.10 \mathrm{~mol} \mathrm{~L}^{-1} \mathrm{HNO}_{3}$.[29-30] The certified reference material of NMIJ CRM 7532-a was analyzed. The extracted solutions were measured by HPLC-ICP-MS with the $\mathrm{C}_{18}$ ODS column using the eluent containing an ion pair reagent.[28-34] As(III), As(V) and DMA were detected after extraction using $0.15 \mathrm{~mol} \mathrm{~L}^{-1} \mathrm{HNO}_{3}$ and $0.28 \mathrm{~mol} \mathrm{~L}^{-1} \mathrm{HNO}_{3}$ (Figure 2). On the other hand, As(V) and DMA, but not As(III), were detected in the extraction solution of 0.30 mol L ${ }^{-1} \mathrm{H}_{2} \mathrm{O}_{2}$ and $0.20 \mathrm{~mol} \mathrm{~L}^{-1} \mathrm{H}_{2} \mathrm{O}_{2}+0.10 \mathrm{~mol} \mathrm{~L}^{-1} \mathrm{HNO}_{3}$ (Figure 3), because almost all As(III) was oxidized to $\mathrm{As}(\mathrm{V})$ during the extraction process.[30] All the extraction efficiencies were approximately $100 \%$, since the inorganic and total arsenic concentrations were in good agreement with the certified values (Figure 4). The authors reported in the previous report that almost $100 \%$ of the arsenic species were extracted by the heat assisted technique with acidic solvents.[30]

By the proposed method, the total inorganic arsenic is determined HPLC-ICP-MS regardless of $\mathrm{As}(\mathrm{III})$ and $\mathrm{As}(\mathrm{V})$, since they are eluted at the same retention time using $\mathrm{C}_{18} \mathrm{ACR}$ column in HPLC. The conversion of As(III) into As(V) is not strictly necessary in the method. However, there are some reports that the detection performances of $\mathrm{As}(\mathrm{III})$ and $\mathrm{As}(\mathrm{V})$ by ICP-OES and ICP-MS are slightly different each other under some operation conditions. [35-37] The single inorganic species $[\mathrm{As}(\mathrm{V})]$ measurements makes the measurement errors smaller than the two species $[\mathrm{As}(\mathrm{III})$ and $\mathrm{As}(\mathrm{V})]$ measurements and probably increases a precision of the total analysis. The presence of the oxidant $\mathrm{H}_{2} \mathrm{O}_{2}$ in the extraction solution is required for the oxidization of $\mathrm{As}(\mathrm{III})$ during extraction process. $\mathrm{H}_{2} \mathrm{O}_{2}$ solution by itself was able to extract the arsenic species, but the extracted solution was highly viscous, because the proteins in rice flour were not hydrolyzed. As a result, bothering and lengthy filtration was required before chromatographic analysis. The presence of a small amount of $\mathrm{HNO}_{3}$ in extraction solution makes the extracted solution smooth and the filtration easy. Therefore, 
$0.20 \mathrm{~mol} \mathrm{~L}^{-1} \mathrm{H}_{2} \mathrm{O}_{2}+0.10 \mathrm{~mol} \mathrm{~L}^{-1} \mathrm{HNO}_{3}$ was selected as the extraction solvent.

Extraction time is obviously important for a rapid monitoring test. The extraction efficiency of the heat assisted method was investigated at $100{ }^{\circ} \mathrm{C}$ using the following extraction solvents; $0.15 \mathrm{~mol} \mathrm{~L}^{-1} \mathrm{HNO}_{3}$ and $0.20 \mathrm{~mol} \mathrm{~L}^{-1} \mathrm{H}_{2} \mathrm{O}_{2}+0.10 \mathrm{~mol} \mathrm{~L}^{-1} \mathrm{HNO}_{3}$. Results are shown in Figure 5. The extraction time 0 is non-heating extraction process, and it just stood at room temperature for $2 \mathrm{~h}$. The extraction efficiency of non-heating process for inorganic arsenic was approximately $94 \%$. The complete extraction of inorganic arsenic was achieved in $15 \mathrm{~min}$ at $100{ }^{\circ} \mathrm{C}$, when $0.20 \mathrm{~mol} \mathrm{~L}^{-1} \mathrm{H}_{2} \mathrm{O}_{2}+0.10 \mathrm{~mol} \mathrm{~L}^{-1} \mathrm{HNO}_{3}$ was used.

The working efficiency of monitoring tests for inorganic arsenic analysis is estimated based on the Codex Alimentarius survey method. The working efficiencies are summarized in the Table 2. The proposed technique will reduce approximately $40 \%$ of total measurement time, $50 \%$ of Ar consumption of ICP-MS, and 30\% of eluent consumption of HPLC, comparing with CODEX Alimentarius survey method.

\subsection{Application}

The proposed method using $\mathrm{C}_{18}$ ACR was applied to the analysis of the CRMs (Figure 6). Analytical results of the inorganic arsenic were in good agreement with the certified values (Table 3).

The certified values of NMIJ CRM 7532-a are as follows; inorganic arsenic $0.298 \pm 0.008$ $\mathrm{mg} \mathrm{kg}{ }^{-1}$ and DMA $0.0186 \pm 0.0008 \mathrm{mg} \mathrm{kg}^{-1}$ as As (the figure following \pm indicates is the expanded uncertainty with $k=2 ; k$ indicates the coverage factor), and those of NMIJ CRM 7533-a are; inorganic arsenic $0.530 \pm 0.016 \mathrm{mg} \mathrm{kg}^{-1}$ and DMA $0.092 \pm 0.004 \mathrm{mg} \mathrm{kg}^{-1}$ as As $(k=2)$. Those of NIST SRM are as follows; inorganic arsenic is $0.092 \pm 0.010 \mathrm{mg} \mathrm{kg}^{-1}$, DMA $0.180 \pm 0.012 \mathrm{mg} \mathrm{kg}^{-1}$, and of MMA $0.0116 \pm 0.0035 \mathrm{mg} \mathrm{kg}^{-1}$ as As $(k=2)$.

The measurement precision for inorganic arsenic was around $3 \%$, even when the rice flour containing inorganic arsenic was less than $0.1 \mathrm{mg} \mathrm{kg}^{-1}\left(5 \mathrm{ng} \mathrm{g}^{-1} \mathrm{As}\right.$ in a measurement solution: $\left.0.1 \mathrm{mg} \mathrm{kg}^{-1} \times 0.5 \mathrm{~g} / 10 \mathrm{~g}\right)$.

\section{Conclusions}

A rapid monitoring method for inorganic arsenic in rice flour was achieved with HPLC-ICP-MS using $\mathrm{C}_{18}$ ACR ODS column. By the proposed method, As(III) and As(V) were completely separated from organic arsenic compounds and eluted at the same chromatographic retention times using simple component eluent, and thus they were detected as the inorganic arsenic at a time. Therefore, it was possible to measure inorganic arsenic selectively, easily and quickly. Moreover, the simple and dilute one component of the chromatographic eluent substantially reduces the deterioration of analytical performances of 
columns and a detector of HCPLC-ICP-MS. Prior to HPLC-ICP-MS determination, the heat assisted extraction was applied to the extraction of arsenic compounds from rice flour. The $\mathrm{H}_{2} \mathrm{O}_{2}+\mathrm{HNO}_{3}$ extraction solvent can extract arsenic compounds efficiently and oxidize As(III) to $\mathrm{As}(\mathrm{V})$ during the extraction process. It facilitates a reliable separation and determination of arsenic species for HPCL-ICP-MS, since it hydrolyzed proteins in extraction solution.

The proposed method requires a single standard solution, $\mathrm{As}(\mathrm{V})$, for inorganic arsenic determination, since the $\mathrm{As}(\mathrm{III})$ and $\mathrm{As}(\mathrm{V})$ are measured as a single peak of the total inorganic arsenic and Almost all $\mathrm{As}(\mathrm{III})$ is oxidized to $\mathrm{As}(\mathrm{V})$ during the extraction process. Low concentration levels of $\mathrm{As}(\mathrm{III})$ and $\mathrm{As}(\mathrm{V})$ in standard solutions sometimes interchange by oxidation-reduction reactions and their detection sensitivities are sometimes different in ICP-MS measurement. Those events can lead us to measurement errors when As(III) and $\mathrm{As}(\mathrm{V})$ are determined. No error caused by $\mathrm{As}(\mathrm{III})$ - As(V) interchange can occur in the proposed method.

The presented method was developed specifically for the rapid monitoring of inorganic arsenic in rice flour. It is also useful for monitoring inorganic arsenic in other environmental and food samples. The accurate evaluation methods might be necessary when the concentration of inorganic arsenic in a sample is very close to the tolerance values.

\section{Acknowledgment:}

Savarin Sinaviwat thanks the Royal Thai Scholarship for financial support.

\section{References}

[1] S. M. Cohen, L. L. Arnold, M. Eldan, A. S. Lewis, B. D. Beck, Methylated arsenicals: The implications of metabolism and carcinogenicity studies in rodents to human risk assessment, Crit. Rev. Toxicol., 36 (2006) 99-133.

[2] K. A. Francesconi, R. Tanggaar, C. J. McKenzie, W. Goessler, Arsenic metabolites in human urine after ingestion of an arsenosugar, Clin. Chem., 48 (2002) 92-101.

[3] Z. Gong, X. Lu, M. Ma, C. Watt, X. Chris Le, Arsenic speciation analysis, Talanta, 58 (2002) 77-96.

[4] Food and Agriculture Organization of the United Nations, Website: http://www.fao.org/news/story/en/item/238558/icode/

[5] The CODEX Alimentarius, Website: http://www.fao.org/fao-who-codexalimentarius/en/ [6] A. H. Petursdottir, J. J. Sloth, J. Feldmann, Introduction of regulations for arsenic in feed and food with emphasis on inorganic arsenic, and implications for analytical chemistry, Anal. Bioanal. Chem., 407 (2015) 8385-8396.

[7] P. N. Williams, A. H. Price, A. Raab, S. A. Hossin, J. Feldmann, A. A. Meharg, Variation in 
362

363

364

365

366

367

368

369

370

371

372

373

374

375

376

377

378

379

380

381

382

383

384

385

386

387

388

389

390

391

392

393

394

395

396

397

arsenic speciation and concentration in paddy rice related to dietary exposure, Environ. Sci Technol., 39 (2005) 5531-5540.

[8] D. T. Heitkemper, N. P. Vela, K. R. Stewart, C. S. Westphal, Determination of total and speciated arsenic in rice by ion chromatography and inductively coupled plasma mass spectrometry, J. Anal. At. Spectrom., 16 (2001) 299-306.

[9] J.-H. Huang, G. Ilgen, P. Fecher, Quantitative chemical extraction for arsenic speciation in rice grain, J. Anal. At. Spectrom., 25 (2010) 800-802.

[10] J.-H. Huang, P. Fecher, G. Ilgen, K. N. Hu, J. Yang, Speciation of arsenite and arsenate in rice grain - verification of nitric acid based extraction method and mass sample survey, Food Chem., 130 (2012) 453-459.

[11] The CODEX Alimentarius, Website: ftp://ftp.fao.org/codex/meetings/cccf/cccf8/

[12] U.S. Food and Drug Administration, Elemental Analysis Manual for Food and Related Products, 4.11 Arsenic Speciation in Rice and Rice Products Using High Performance Liquid Chromatography-Inductively Coupled Plasma-Mass Spectrometric Determination, Version Graft 1.1, November 2012, Website: http://www.fda.gov/Food/FoodScienceResearch/LaboratoryMethods/ucm2006954.htm.

[13] C. B'Hymer, K. L. Sutton, J. A. Caruso, Comparison of four nebulizer-spray chamber interfaces for the high-performance liquid chromatographic separation of arsenic compounds using inductively coupled plasma mass spectrometric detection, J. Anal. At. Spectrom., 13 (1998) 855-858.

[14] X. C. Le, W. R. Cullen, K. J. Reimer, Speciation of arsenic compounds by HPLC with hydride generation atomic absorption spectrometry and inductively coupled plasma mass spectrometry detection, Talanta, 41 (1994) 495-502.

[15] K. L. Ackley, C. B'Hymer, K. L. Sutton, J. A. Caruso, Speciation of arsenic in fish tissue using microwave-assisted extraction followed by HPLC-ICP-MS, J. Anal. At. Spectrom., 14 (1999) 845-850.

[16] A. J. Signes-Pastor, C. Deacon, R. O. Jenkins, P. I. Haris, A. A. Carbonell-Barrachina, A. A. Meharg, Arsenic speciation in Japanese rice drinks and condiments, J. Environ. Monit., 11 (2009) 1930-1934.

[17] G. X. Sun, P. N. Williams, A. M. Carey, Y. G. Zhu, C. Deacon, A. Raab, J. Feldmann, R. M. Islam, A. A. Meharg, Inorganic arsenic in rice bran and its products are an order of magnitude higher than in bulk grain, Environ. Sci. Technol., 42 (2008) 7542-7546.

[18] M. D’Amato, F. Aureli, S. Ciardullo, A. Raggi, F. Cubadda, Arsenic speciation in wheat and wheat products using ultrasound- and microwave-assisted extraction and anion exchange chromatography inductively coupled plasma mass spectrometry, J. Anal. At. Spectrom., 26 (2011) 207-213. 
398 [19] G. Raber, N. Stock, P. Hanel, M. Murko, J. Navratilova, K. A. Francesconi, An improved 399 HPLC-ICPMS method for determining inorganic arsenic in food: Application to rice, wheat and 400 tuna fish, Food Chem., 134 (2012) 524-532.

401 [20] J. L. Guzmán Mar, L. H. Reyes, G. M. Mizanur Rahman, H. M. Skip Kingston, 402 Simultaneous extraction of arsenic and selenium species from rice products by 403 microwave-assisted enzymatic extraction and analysis by ion chromatography-inductively 404 coupled plasma-mass spectrometry, J. Agric. Food Chem., 57 (2009) 3005-3013.

405 [21] U. Kohlmeyer, E. Jantzen, J. Kuballa, Benefits of high resolution IC-ICP-MS for the 406 routine analysis of inorganic and organic arsenic species in food products of marine and 407 terrestrial origin, Anal. Bioanal. Chem., 377 (2003) 6-13.

408 [22] E. Sanz, R. Muñoz, C. Cámara, A rapid and novel alternative to conventional sample 409 treatment for arsenic speciation in rice using enzymatic ultrasonic probe, Anal. Chim. Acta, 535 $410 \quad$ (2005) 227-235.

411 [23] U.S. Food and Drug Administration, Analytical results from inorganic arsenic in rice and 412 rice products sampling, September 2013, Website: 413 http://www.fda.gov/Food/FoodborneIllnessContaminants/Metals/ucm319870.htm

414 [24] S. Nookabkaew, N. Rangkadilok, C. Mahidol, G. Promsuk, J. Satayavivad, Determination 415 of arsenic species in rice from Thailand and other Asian countries using simple extraction and 416 HPLC-ICP-MS analysis, J. Agric. Food Chem., 61 (2013) 6991-6998.

417 [25] H. R. Hansen, A. Raab, A. H. Price, G. Duan, Y. Zhu, G. J. Norton, J. Feldmann, A. A. 418 Meharg, Identification of tetramethylarsonium in rice grains with elevated arsenic content, J. 419 Environ. Monit., 13 (2011) 32-34.

420 [26] E. Bralatei, S. Lacan, E. M. Krupp, J. Feldmann, Detection of inorganic arsenic in rice 421 using a field test kit: A screening method, Anal. Chem., 87 (2015) 11271-11276.

422 [27] B. P. Jackson, Fast ion chromatography-ICP-QQQ for arsenic speciation, J. Anal. At. 423 Spectrom., 30 (2015) 1405-1407.

424 [28] T. Narukawa, E. Matsumoto, T. Nishimura, A. Hioki, Reversed phase column 425 HPLC-ICP-MS conditions for arsenic speciation analysis of rice flour, Anal. Sci., 31 (2015) $426 \quad 521-527$.

427 [29] M. B. de la Calle, H. Emteborg, T. P. J. Linsinger, R. Montoro, J. J. Sloth, R. Rubio, M. J. 428 Baxter, J. Feldmann, P. Vermaercke, G. Raber, Does the determination of inorganic arsenic in 429 rice depend on the method?, Trend. Anal. Chem., 30 (2011) 641-651.

430 [30] T. Narukawa, T. Suzuki, K. Inagaki, A. Hioki, Extraction techniques for arsenic species in 431 rice flour and their speciation by HPLC-ICP-MS, Talanta, 130 (2014) 213-220.

432 [31] T. Narukawa, K. Chiba, Heat assisted aqueous extraction of rice flour for arsenic speciation 433 analysis, J. Agric. Food Chem., 58 (2010) 8183-8188. 
434 [32] T. Narukawa, A. Hioki, K. Chiba, Speciation and monitoring test for inorganic arsenic in 435 white rice flour, J. Agric. Food Chem., 60 (2012) 1122-1127.

436 [33] T. Narukawa, K. Inagaki, T. Kuroiwa, K. Chiba, The extraction and speciation of arsenic in 437 rice flour by HPLC-ICP-MS, Talanta, 77 (2008) 427-432.

438 [34] T. Narukawa, E. Matsumoto, T. Nishimura, A. Hioki, Determination of sixteen elements 439 and arsenic species in brown, polished and milled rice, Anal. Sci., 30 (2014) 245-250.

440 [35] J. T. Creed, T. D. Martin, C. A. Brockhoff, Ultrasonic nebulization and arsenic valence state 441 considerations prior to determination via inductively coupled plasma mass spectrometry, J. Anal. 442 At. Spectrom., 10 (1995) 443-447.

443 [36] T. Narukawa, T. Kuroiwa, K. Chiba, Mechanism of sensitivity difference between trivalent 444 inorganic As species [As(III)] and pentavalent species [As(V)] with inductively coupled plasma 445 spectrometry, Talanta, 73 (2007) 157-165.

446 [37] T. Narukawa, K. Chiba, T. Kuroiwa, K. Inagaki, Differences in sensitivity between As(III) 447 and $\mathrm{As}(\mathrm{V})$ measured by inductively coupled plasma spectrometry and the factors affecting the 448 incoherent molecular formation (IMF) effect in the plasma, J. Anal. At. Spectrom., 25 (2010) $449 \quad 1682-1687$.

450 
Table 1 Effect of carbon length of ODS column on retention times of arsenic species.

\begin{tabular}{cccccc}
\hline $\begin{array}{c}\text { Carbon } \\
\text { length }\end{array}$ & $\mathrm{C}_{8}$ & $\mathrm{C}_{18}$ & $\mathrm{C}_{28}$ & $\mathrm{C}_{30}$ & $\mathrm{C}_{18} \mathrm{ACR}$ \\
\hline \multicolumn{5}{c}{ Retention Time (min) } \\
\hline As(III) & 4.30 & 3.26 & 3.78 & 3.76 & 2.79 \\
(peak start) & $(4.11)$ & $(3.06)$ & $(3.62)$ & $(3.62)$ & $(2.70)$ \\
As(V) & 4.20 & 3.22 & 3.73 & 3.74 & 2.79 \\
(peak start) & $(4.04)$ & $(3.04)$ & $(3.62)$ & $(3.60)$ & $(2.70)$ \\
MMA & 4.34 & 3.52 & 4.20 & 4.15 & 2.98 \\
DMA & 4.53 & 3.73 & 4.38 & 4.33 & 3.03 \\
TeMA & 4.79 & 3.68 & 4.22 & 4.18 & 2.69 \\
\hline
\end{tabular}

454 Flow rate: $0.75 \mathrm{~mL} \mathrm{~min}^{-1}$.

455 Eluent: $1 \mathrm{mmol} \mathrm{L}^{-1}$ diammonium hydrogen phosphate buffer / $0.05 \%$ methanol $(\mathrm{pH} 2.0$ by 456 $\left.\mathrm{HNO}_{3}\right)$

457

458

459

460

461

462

463

464

465

466

467

468

469

470

471

472

473

474

475

476

477 
480 Table 2 Working efficiency for monitoring test of inorganic arsenic in rice flour samples.

\begin{tabular}{|c|c|c|c|}
\hline Content & Codex* & US FDA & Proposed method \\
\hline \multicolumn{4}{|l|}{ ANALYTICAL TIME } \\
\hline \multicolumn{4}{|l|}{ Sample pretreatment } \\
\hline Sample taken (e.g. $n=20)^{* *}$ & $20 \mathrm{~min}$ & $20 \mathrm{~min}$ & $20 \mathrm{~min}$ \\
\hline Addition of extracting solvent** & $10 \mathrm{~min}$ & $10 \mathrm{~min}$ & $10 \mathrm{~min}$ \\
\hline Heating time (Extraction) & $120 \mathrm{~min}$ & $90 \mathrm{~min}$ & $15 \min$ \\
\hline Cooling time** & $30 \mathrm{~min}$ & $30 \mathrm{~min}$ & $30 \mathrm{~min}$ \\
\hline Centrifugation time ${ }^{* *}$ & $10 \mathrm{~min}$ & $10 \mathrm{~min}$ & $10 \mathrm{~min}$ \\
\hline Filtration time $(n=20)^{* *}$ & $20 \mathrm{~min}$ & $20 \mathrm{~min}$ & $20 \mathrm{~min}$ \\
\hline Dilution $(n=20)$ & $100 \mathrm{~min}$ & $100 \mathrm{~min}$ & $60 \mathrm{~min}$ \\
\hline \multicolumn{4}{|l|}{ Calibration standards } \\
\hline $\begin{array}{l}\text { Preparation of standard solution** } \\
\text { (e.g. four points, three step dilution) }\end{array}$ & $60 \mathrm{~min}$ & $60 \mathrm{~min}$ & $60 \mathrm{~min}$ \\
\hline \multicolumn{4}{|l|}{ Measurement } \\
\hline Runtime ( $n=24)$ & $6 \min \times 24$ & $15 \min \times 24$ & $3 \min \times 24$ \\
\hline (samples + standards) & $=144 \mathrm{~min}$ & $=360 \mathrm{~min}$ & $=72 \mathrm{~min}$ \\
\hline Total analytical time (min) & $514 \mathrm{~min}$ & $700 \mathrm{~min}$ & $297 \mathrm{~min}$ \\
\hline Efficiency factor (based on the Codex) & 1.00 & 1.36 & 0.58 \\
\hline \multicolumn{4}{|l|}{ Equipment } \\
\hline \multirow[t]{2}{*}{ Ar gas consumption of ICP-MS } & $\begin{array}{c}20 \mathrm{~L} / \min \times 144 \\
\min \end{array}$ & $\begin{array}{l}20 \mathrm{~L} / \mathrm{min} \times \\
360 \mathrm{~min}\end{array}$ & $\begin{array}{c}20 \mathrm{~L} / \min \times 72 \\
\min \end{array}$ \\
\hline & $=2880 \mathrm{~L}$ & $=7200 \mathrm{~L}$ & $=1440 \mathrm{~L}$ \\
\hline Efficiency factor (based on the Codex) & 1.00 & 2.50 & 0.50 \\
\hline \multirow[t]{2}{*}{ Eluent consumption of LC system } & $\begin{array}{c}0.75 \mathrm{~mL} / \mathrm{min} * \\
144 \mathrm{~min}\end{array}$ & $\begin{array}{c}1.0 \mathrm{~mL} / \mathrm{min} \\
\min \end{array}$ & $\begin{array}{c}1.0 \mathrm{~mL} / \mathrm{min} * 72 \\
\min \end{array}$ \\
\hline & $=108 \mathrm{~mL}$ & $=360 \mathrm{~mL}$ & $=72 \mathrm{~mL}$ \\
\hline Efficiency factor (based on the Codex) & 1.00 & 3.33 & 0.67 \\
\hline
\end{tabular}

* Codex Alimentarius survey method, ** Common factor

Except a dry mass correction factor experiment 
Table 3 Inorganic arsenic (i-As) in rice flour samples obtained by the proposed method with $\mathrm{C}_{18}$ ACR column $\left(\mathrm{mg} \mathrm{kg}^{-1}\right)$.

\section{Extraction 1}

\section{Extraction 2}

NMIJ CRM 7532-a

Certified value of i-As

$$
0.298 \pm 0.008(k=2)
$$

Result*

$0.295 \pm 0.002$

$0.296 \pm 0.002$

NMIJ CRM 7533-a

Certified value of i-As

$$
0.530 \pm 0.016(k=2)
$$

Result*

$0.522 \pm 0.007$

$0.528 \pm 0.007$

NIST SRM $1568 \mathrm{~b}$

Certified value of $i-A s$

$$
0.092 \pm 0.010(k=2)
$$

Result*

$0.093 \pm 0.003$

$0.094 \pm 0.003$

Extraction time, 1: $15 \mathrm{~min}, 2: 30 \mathrm{~min}$

Extraction conditions: Temperature $100^{\circ} \mathrm{C}$, Extracting solvent: $0.2 \mathrm{M} \mathrm{H}_{2} \mathrm{O}_{2}+0.1 \mathrm{M} \mathrm{HNO}_{3}$

$*$ Mean $\pm \mathrm{SD}(n=3)$

487

488

489

490

491

492

493

494

495

496

497

498

499

500

501 
505 Figure 1 Retention times of arsenic species according to carbon length of ODS column.

506 Eluent: $0.01 \mathrm{M} \mathrm{HNO}_{3} / 0.05 \%$ methanol, Flow rate: $0.75 \mathrm{~mL} \mathrm{~min}^{-1}$.

507

508

509

510

511

512

513

514

515

516

517 Column: $\mathrm{C}_{18}$ ODS (particle size $5 \mu \mathrm{m}, 250 \mathrm{~mm}$ x ID $4.6 \mathrm{~mm}$ ), Eluent: $10 \mathrm{mmol} \mathrm{L}^{-1}$ sodium 518 1-butanesulfonate / $4 \mathrm{mmol} \mathrm{L}^{-1}$ malonic acid / $4 \mathrm{mmol} \mathrm{L}^{-1}$ tetramethylammonium hydroxide / $5190.05 \%$ methanol (pH 3.0), Flow rate of $0.75 \mathrm{~mL} \mathrm{~min}^{-1}$, Sample; NMIJ CRM 7532-a, Peaks 520 521

522

523

524

525

526

527

528

529

530

531

532

533

534

535

536 537

Figure 2 Chromatogram of the arsenic species in brown rice flour following extraction with solvent of $0.15 \mathrm{~mol} \mathrm{~L}^{-1} \mathrm{HNO}_{3}$.

Column: $\mathrm{C}_{18}$ ODS (particle size $5 \mu \mathrm{m}, 250 \mathrm{~mm}$ x ID $4.6 \mathrm{~mm}$ ), Eluent: $10 \mathrm{mmol} \mathrm{L}^{-1}$ sodium 1-butanesulfonate / $4 \mathrm{mmol} \mathrm{L}-1$ malonic acid / $4 \mathrm{mmol} \mathrm{L}^{-1}$ tetramethylammonium hydroxide / $0.05 \%$ methanol (pH 3.0), Flow rate: $0.75 \mathrm{~mL} \mathrm{~min}^{-1}$, Sample; NMIJ CRM 7532-a, Peaks from the left: 1st peak As(V), 2nd peak As(III), 3rd peak DMA.

Figure 3 Chromatogram of the arsenic species in brown rice flour following extraction with from the left: 1st peak As(V), 2nd peak DMA.

Figure 4 Influence of solvents on extraction efficiencies.

- Inorganic arsenic (i-As), $\square$ Total arsenic(total As), Certified: Certified values of inorganic arsenic and total arsenic $(k=1)$, i-As 1 and total As 1: $0.15 \mathrm{~mol} \mathrm{~L}^{-1} \mathrm{HNO}_{3}$ extraction, i-As 2 and total As 2: $0.28 \mathrm{~mol} \mathrm{~L}^{-1} \mathrm{HNO}_{3}$ extraction, i-As 3 and total As 3: $0.30 \mathrm{~mol} \mathrm{~L}^{-1} \mathrm{H}_{2} \mathrm{O}_{2}$ extraction, i-As 4 and total As 4: $0.20 \mathrm{~mol} \mathrm{~L}^{-1} \mathrm{H}_{2} \mathrm{O}_{2}+0.10 \mathrm{~mol} \mathrm{~L}^{-1} \mathrm{HNO}_{3}$ extraction, Sample: NMIJ CRM 7532-a brown rice, Extraction; temperature $100{ }^{\circ} \mathrm{C}$, time $2 \mathrm{~h}$, Column: $\mathrm{C}_{18}$ ODS ACR (particle size $5 \mu \mathrm{m}, 250 \mathrm{~mm}$ x ID $4.6 \mathrm{~mm}$ ), Eluent: $1 \mathrm{mmol} \mathrm{L}^{-1}$ diammonium hydrogen phosphate (pH 2.0) / $0.05 \%$ methanol, Flow rate; $0.75 \mathrm{~mL} \mathrm{~min}^{-1}$.

Figure 5 Effect of extraction time on extraction efficiency.

- $0.15 \mathrm{~mol} \mathrm{~L}^{-1} \mathrm{HNO}_{3}$ extraction, $0.20 \mathrm{~mol} \mathrm{~L}^{-1} \mathrm{H}_{2} \mathrm{O}_{2}+0.10 \mathrm{~mol} \mathrm{~L}^{-1} \mathrm{HNO}_{3}$ extraction, Sample: NMIJ CRM 7532-a brown rice,

Extraction temperature: $100{ }^{\circ} \mathrm{C}, 0 *$ : Non-heating extraction at room temperature for $2 \mathrm{~h}$.

36 Figure 6 Chromatogram of the arsenic species in NMIJ CRM 7533-a and NIST SRM 1568b rice flour. 
538 Column: $\mathrm{C}_{18}$ ODS ACR (particle size $5 \mu \mathrm{m}, 250 \mathrm{~mm}$ x ID $4.6 \mathrm{~mm}$ ), Eluent: $1 \mathrm{mmol} \mathrm{L}{ }^{-1}$ 539 diammonium hydrogen phosphate $(\mathrm{pH} 2.0) / 0.05 \%$ methanol at a flow rate of $0.75 \mathrm{~mL} \mathrm{~min}^{-1}$ 540 and $1.0 \mathrm{~mL} \mathrm{~min}^{-1}$ (proposed optimized condition), Extracting solvent: $0.15 \mathrm{~mol} \mathrm{~L}^{-1} \mathrm{HNO}_{3}$, Peaks 541 from the left: 1st peak i-As, 2nd peak Organoarsenic species.

542

543

544

545

546

547 
561

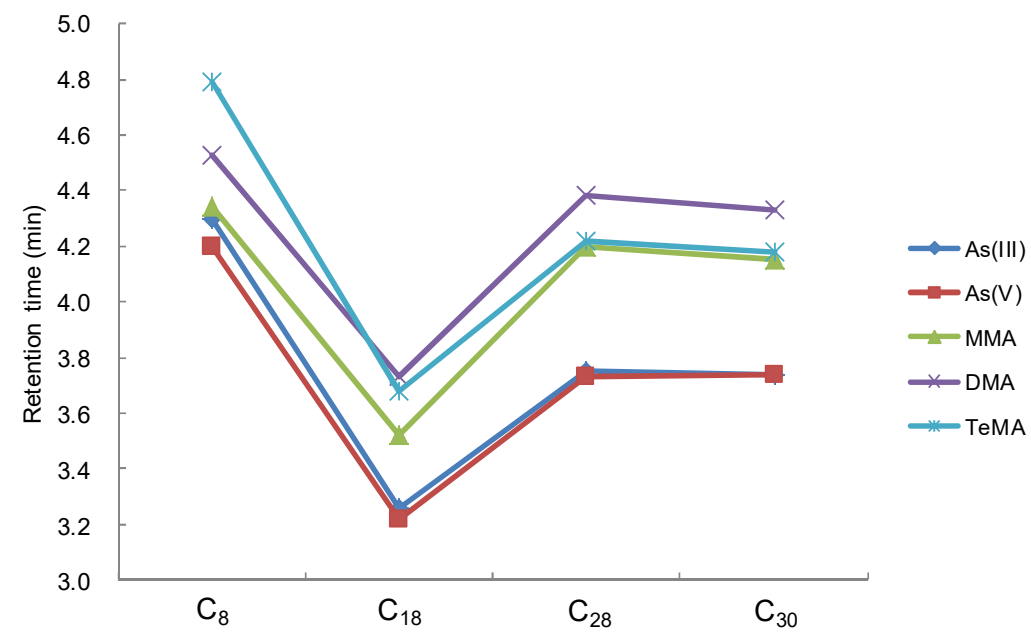

562

563

564 Figure 1 Retention times of arsenic species according to carbon length of ODS column.

565 Eluent: $0.01 \mathrm{M} \mathrm{HNO}_{3} / 0.05 \%$ methanol, Flow rate: $0.75 \mathrm{~mL} \mathrm{~min}^{-1}$.

566

567

568

569

570

571

572

573

574

575

576

577

578

579

580

581

582

583 
595

596

597

598

599

600

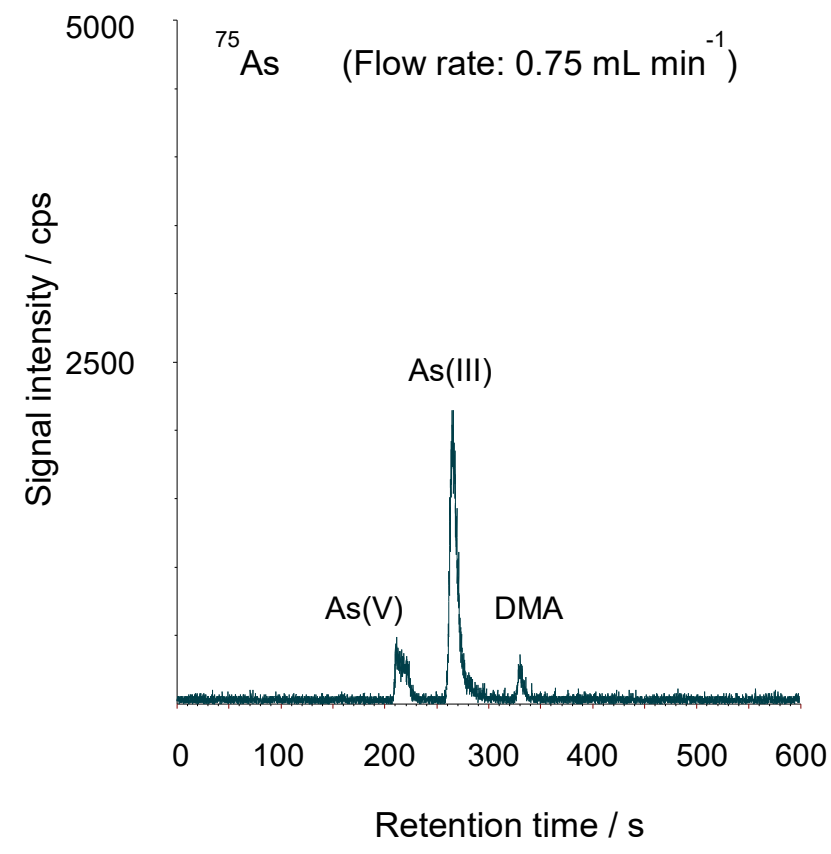

601

602 Figure 2 Chromatogram of the arsenic species in brown rice flour following extraction with 603 solvent of $0.15 \mathrm{~mol} \mathrm{~L}^{-1} \mathrm{HNO}_{3}$.

604 Column: $\mathrm{C}_{18}$ ODS (particle size $5 \mu \mathrm{m}, 250 \mathrm{~mm}$ x ID $4.6 \mathrm{~mm}$ ), Eluent: $10 \mathrm{mmol} \mathrm{L}^{-1}$ sodium 605 1-butanesulfonate / $4 \mathrm{mmol} \mathrm{L}^{-1}$ malonic acid / $4 \mathrm{mmol} \mathrm{L}^{-1}$ tetramethylammonium hydroxide / $6060.05 \%$ methanol (pH 3.0), Flow rate: $0.75 \mathrm{~mL} \mathrm{~min}^{-1}$, Sample; NMIJ CRM 7532-a, Peaks from 607 the left: 1st peak As(V), 2nd peak As(III), 3rd peak DMA.

608

609

610

611

612

613

614

615

616

617

618

619 
626

627

628

629

630

631

632

633

634

635

636

637

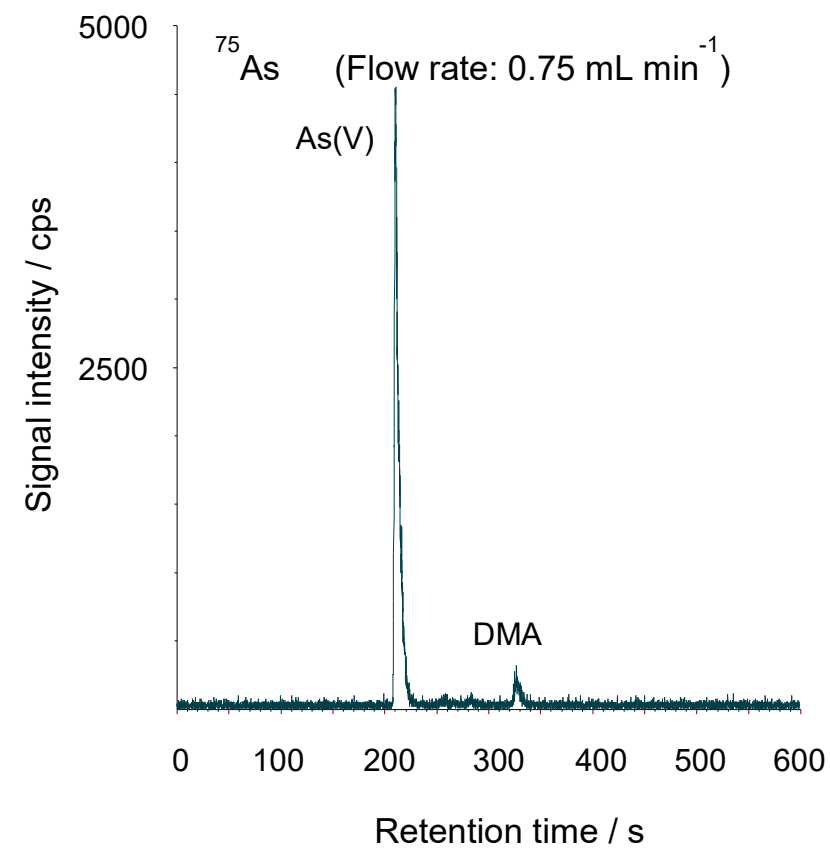

638

639 Figure 3 Chromatogram of the arsenic species in brown rice flour following extraction with 640 solvent of $0.30 \mathrm{~mol} \mathrm{~L}^{-1} \mathrm{H}_{2} \mathrm{O}_{2}$.

641 Column: $\mathrm{C}_{18}$ ODS (particle size $5 \mu \mathrm{m}, 250 \mathrm{~mm}$ x ID $4.6 \mathrm{~mm}$ ), Eluent: $10 \mathrm{mmol} \mathrm{L}^{-1}$ sodium

642 1-butanesulfonate / $4 \mathrm{mmol} \mathrm{L}^{-1}$ malonic acid / $4 \mathrm{mmol} \mathrm{L}^{-1}$ tetramethylammonium hydroxide /

$6430.05 \%$ methanol ( $\mathrm{pH}$ 3.0), Flow rate of $0.75 \mathrm{~mL} \mathrm{~min}^{-1}$, Sample; NMIJ CRM 7532-a, Peaks

644 from the left: 1st peak As(V), 2nd peak DMA.

645

646

647

648

649

650

651

652

653

654

655 
663

664

665

666

667

668

669

670

671

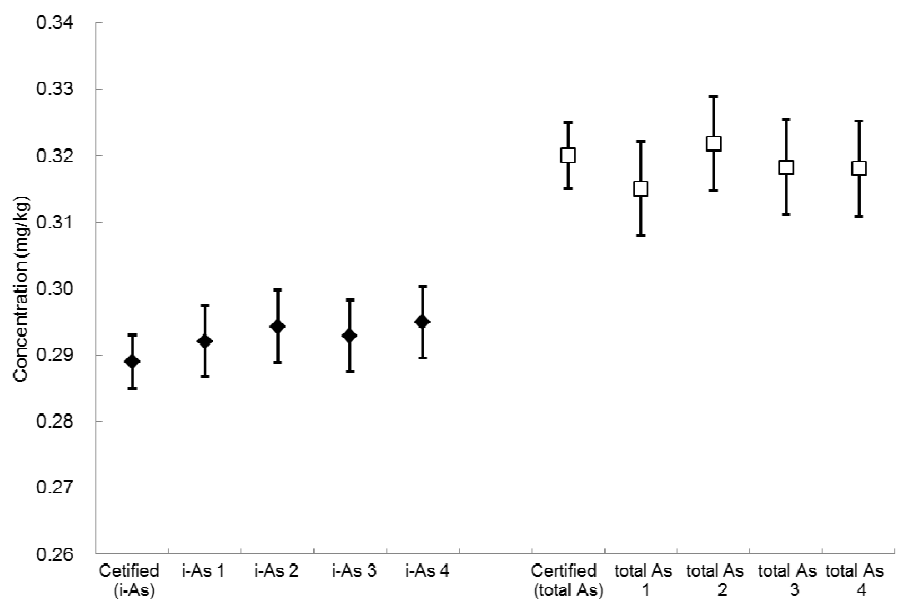

672

673

674 Figure 4 Influence of solvents on extraction efficiencies.

675 Inorganic arsenic (i-As), $\square$ Total arsenic(total As), Certified: Certified values of inorganic 676 arsenic and total arsenic $(k=1)$, i-As 1 and total As $1: 0.15 \mathrm{~mol} \mathrm{~L}^{-1} \mathrm{HNO}_{3}$ extraction, i-As 2 and 677 total As 2: $0.28 \mathrm{~mol} \mathrm{~L}^{-1} \mathrm{HNO}_{3}$ extraction, i-As 3 and total As 3: $0.30 \mathrm{~mol} \mathrm{~L}^{-1} \mathrm{H}_{2} \mathrm{O}_{2}$ extraction, 678 i-As 4 and total As 4: $0.20 \mathrm{~mol} \mathrm{~L}^{-1} \mathrm{H}_{2} \mathrm{O}_{2}+0.10 \mathrm{~mol} \mathrm{~L}^{-1} \mathrm{HNO}_{3}$ extraction, Sample: NMIJ CRM 679 7532-a brown rice, Extraction; temperature $100{ }^{\circ} \mathrm{C}$, time $2 \mathrm{~h}$, Column: $\mathrm{C}_{18}$ ODS ACR (particle 680 size $5 \mu \mathrm{m}, 250 \mathrm{~mm}$ x ID $4.6 \mathrm{~mm}$ ), Eluent: $1 \mathrm{mmol} \mathrm{L}^{-1}$ diammonium hydrogen phosphate ( $\mathrm{pH}$ $6812.0) / 0.05 \%$ methanol, Flow rate; $0.75 \mathrm{~mL} \mathrm{~min}^{-1}$.

682

683

684

685

686

687

688

689

690

691 
692

693

694

695

696

697

698

699

700

701

702

703

704

705

706

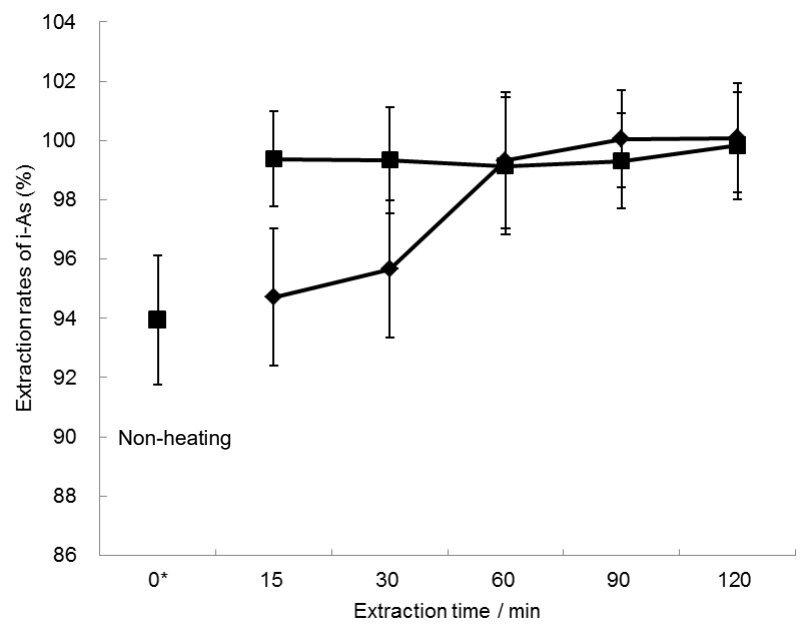

707

708

Figure 5 Effect of extraction time on extraction efficiency.

709

- $0.15 \mathrm{~mol} \mathrm{~L}^{-1} \mathrm{HNO}_{3}$ extraction,

$0.20 \mathrm{~mol} \mathrm{~L}^{-1} \mathrm{H}_{2} \mathrm{O}_{2}+0.10$ mol L${ }^{-1} \mathrm{HNO}_{3}$ extraction,

710

Sample: NMIJ CRM 7532-a brown rice, Extraction temperature: $100{ }^{\circ} \mathrm{C}, 0^{*}$ : Non-heating

711 extraction at room temperature for $2 \mathrm{~h}$.

712

713

714

715

716

717

718

719

720

721

722

723

724

725

726

727 


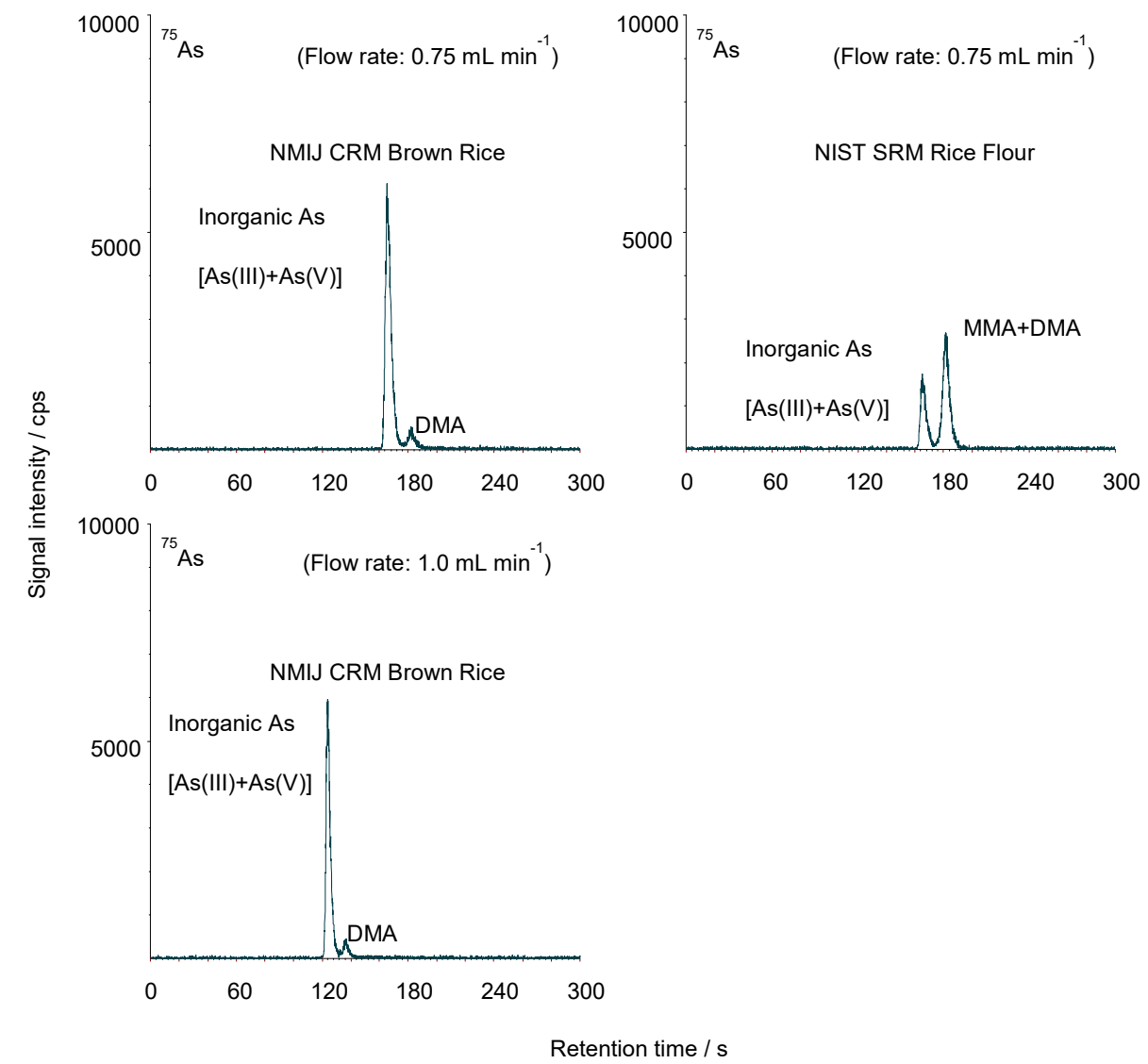

750

751 Figure 6 Chromatogram of the arsenic species in NMIJ CRM 7533-a and NIST SRM 1568b rice 752 flour. Column: $\mathrm{C}_{18}$ ODS ACR (particle size $5 \mu \mathrm{m}, 250 \mathrm{~mm}$ x ID $4.6 \mathrm{~mm}$ ), Eluent: $1 \mathrm{mmol} \mathrm{L}^{-1}$ 753 diammonium hydrogen phosphate $(\mathrm{pH} 2.0) / 0.05 \%$ methanol at a flow rate of $0.75 \mathrm{~mL} \mathrm{~min}^{-1}$ 754 and $1.0 \mathrm{~mL} \mathrm{~min}^{-1}$ (proposed optimized condition), Extracting solvent: $0.15 \mathrm{~mol} \mathrm{~L}^{-1} \mathrm{HNO}_{3}$, Peaks 755 from the left: 1st peak i-As, 2nd peak Organoarsenic species.

756

757

758

759

760

761 
763 Table S1 Measurement parameters and its analytical performances.

ICP-MS Agilent 7500c

Plasma conditions:

$\begin{array}{ll}\text { Incident Rf power } & 1600 \mathrm{~W} \\ \text { Reflected power } & <2 \mathrm{~W} \\ \text { Outer gas flow rate } & \text { Ar } 15 \mathrm{~L} / \mathrm{min} \\ \text { Intermediate gas flow rate } & \text { Ar } 0.9 \mathrm{~L} / \mathrm{min} \\ \text { Carrier gas flow rate } & \text { Ar } 0.8 \mathrm{~L} / \mathrm{min} \\ \text { Make-up gas flow rate } & \text { Ar } 0.4 \mathrm{~L} / \mathrm{min}\end{array}$

Sampling conditions:

Nebulizer

Spray chamber

Sample depth

Collision / reaction mode:

\section{Calibration method}

Dwell time

Data acquisition:

Measured isotopes $(\mathrm{m} / \mathrm{z})$ :

HPLC conditions:

Column

Eluent

Flow rate

Injection volume
Glass $100 \mu \mathrm{L}$ (natural aspirate)

Scott type $\left(2{ }^{\circ} \mathrm{C}\right)$

$7 \mathrm{~mm}$ from work coil

He $3.0 \mathrm{~mL} / \mathrm{min}$

$20 \mathrm{~ms} /$ point

${ }^{75}$ As

ODS columns (particle size of the filler $5 \mu \mathrm{m}$, ID $4.6 \mathrm{~mm} \times 250 \mathrm{~mm}$ ) $1 \mathrm{mmol} \mathrm{L}{ }^{-1}$ diammonium hydrogen phosphate (pH 2.0) / $0.05 \%$ methanol $0.75 \mathrm{~mL} \mathrm{~min}^{-1}$

$20 \mu \mathrm{L}$

Analytical performances:

$$
\begin{array}{ll}
\text { Limit of detection }(3 \sigma) & 0.01 \mathrm{ng} \mathrm{g}^{-1} \text { (as As) } \\
\text { limit of quantitation }(10 \sigma) & 0.03 \mathrm{ng} \mathrm{g}^{-1} \text { (as As) } \\
\text { Analytical precision } & 3 \% \text { for } 5 \mathrm{ng} \mathrm{g}^{-1} \mathrm{As}, 10 \% \text { for } 1 \mathrm{ng} \mathrm{g}^{-1}
\end{array}
$$


Table S2: Tested columns (Column group II)

\begin{tabular}{|c|c|c|c|c|}
\hline Column & Production & $\begin{array}{c}\text { Typical } \\
\text { separation } \\
\text { mode }\end{array}$ & $\begin{array}{c}\text { Particle } \\
\text { size } \\
\text { of filler }\end{array}$ & $\begin{array}{l}\text { Column size }(\mathrm{mm}) \\
\text { Inside diameter } \times \\
\text { Length }\end{array}$ \\
\hline PRP-X100 & Hamilton & Anion-exchange & $10 \mu \mathrm{m}$ & $4.1 \times 150$ \\
\hline IonPac CS12A & Dionex & Cation-exchange & & $3.0 \times 150$ \\
\hline PRP-X300 & Hamilton & Ion-exclusion & $10 \mu \mathrm{m}$ & $4.1 \times 150$ \\
\hline RSpak NN-414 & Showa Denko K.K. & Reversed phase & & $4.6 \times 150$ \\
\hline RSpak NN-614 & Showa Denko K.K. & Reversed phase & & $6.0 \times 150$ \\
\hline CAPCELL CORE & Shiseido Co., Ltd. & Reversed phase & $2.7 \mu \mathrm{m}$ & $4.6 \times 100$ \\
\hline $\begin{array}{c}\text { CAPCELL PAK } \\
\text { ADAM S3 }\end{array}$ & Shiseido Co., Ltd. & Reversed phase & $3 \mu \mathrm{m}$ & $4.6 \times 50$ \\
\hline $\begin{array}{c}\text { CAPCELL PAK } \\
\text { C27 AQ }\end{array}$ & Shiseido Co., Ltd. & Reversed phase & $2.7 \mu \mathrm{m}$ & $4.6 \times 100$ \\
\hline $\begin{array}{l}\text { Shim-pack VP-ODS } \\
\text { C18 }\end{array}$ & Shimadzu Co. & Reversed phase & $5 \mu \mathrm{m}$ & $4.6 \times 250$ \\
\hline Sunrise C18 SAC & $\begin{array}{c}\text { ChromaNik } \\
\text { Technologies Inc. }\end{array}$ & Reversed phase & $5 \mu \mathrm{m}$ & $4.6 \times 250$ \\
\hline
\end{tabular}

*For comparison study, typical column conditions were selected the particle size of filler $5 \mu \mathrm{m}$ and the column size ID $4.6 \mathrm{~mm} \times 250 \mathrm{~mm}$. But, some columns are not on the market: therefore, the different size columns were controlled by its column pressure.

774 Table S3: Components of the tested eluents for column group II

\begin{tabular}{cccc}
\hline Component of eluent & $\begin{array}{c}\text { Concentration range } \\
\left(\mathrm{mmol} \mathrm{L}^{-1}\right)\end{array}$ & $\begin{array}{c}\text { Organic solvent } \\
\text { (Methanol \%) }\end{array}$ & pH range \\
\hline $\mathrm{HNO}_{3}$ & 1 to 10 & 0 to 0.5 & ----- \\
$\mathrm{H}_{2} \mathrm{SO}_{4}$ & 1 to 10 & 0 to 0.5 & ----- \\
Malonic acid & 1 to 5 & 0 to 0.5 & 2 to 4 \\
Malonic acid / $\mathrm{TMAH}$ & 1 to 5 & 0 to 0.5 & 2 to 4 \\
$\mathrm{NH}_{4} \mathrm{H}_{2} \mathrm{PO}_{4}$ & 1 to 20 & 0 to 0.5 & 2 to 8 \\
$\left(\mathrm{NH}_{4}\right)_{2} \mathrm{HPO}_{4}$ & 1 to 20 & 0 to 0.5 & 2 to 8 \\
$\mathrm{Prigine}$ & 5 to 20 & 0 to 0.5 & 2 to 4 \\
$\mathrm{NH}_{4} \mathrm{NO}_{3}$ & 5 to 20 & 0 to 0.5 & 2 to 4 \\
\hline
\end{tabular}




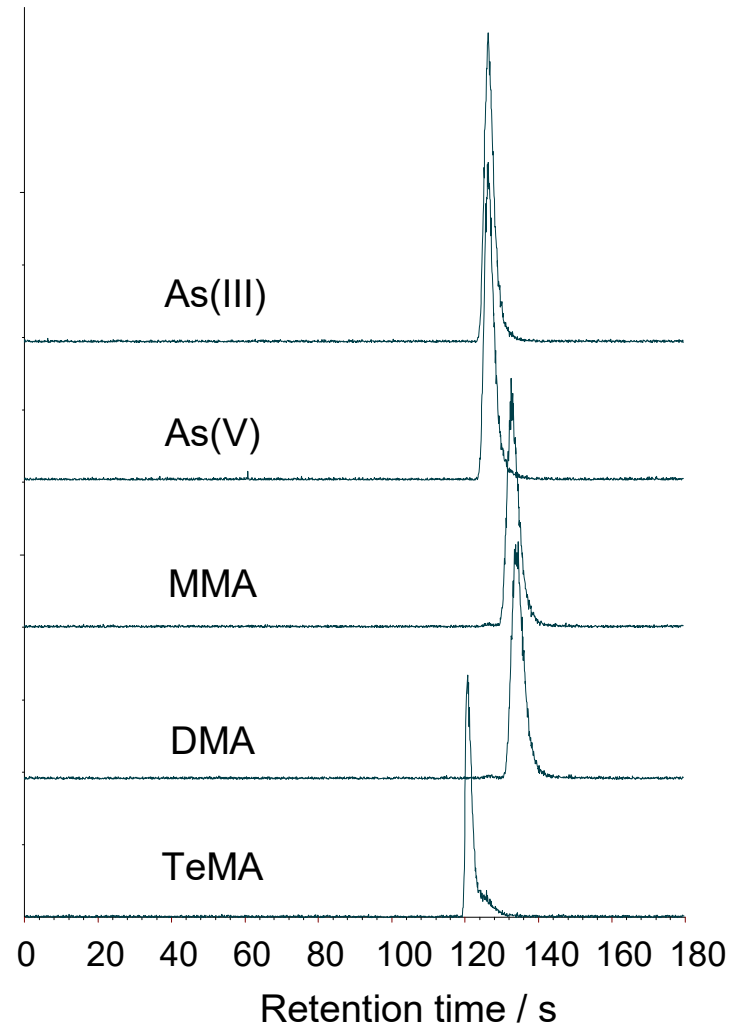

797

798 Figure S1: Chromatogram of each arsenic species under the proposed condition.

799 Column: $\mathrm{C}_{18}$ ODS ACR (particle size $5 \mu \mathrm{m}, 250 \mathrm{~mm}$ x ID $4.6 \mathrm{~mm}$ ), Eluent: $1 \mathrm{mmol} \mathrm{L}{ }^{-1}$ 800 diammonium hydrogen phosphate $(\mathrm{pH} 2.0) / 0.05 \%$ methanol at a flow rate of $1.0 \mathrm{~mL} \mathrm{~min}^{-1}$. 801

802

803

804

805

806

807

808

809

810

811 
836 Figure S2: Chromatogram of the arsenic species with different concentrations.

837 Column: $\mathrm{C}_{18}$ ODS ACR (particle size $5 \mu \mathrm{m}, 250 \mathrm{~mm}$ x ID $4.6 \mathrm{~mm}$ ), Eluent: $1 \mathrm{mmol} \mathrm{L}^{-1}$ 838 diammonium hydrogen phosphate $(\mathrm{pH} 2.0) / 0.05 \%$ methanol at a flow rate of $1.0 \mathrm{~mL} \mathrm{~min}^{-1}$ 839 (proposed optimized condition), i-As: As(III)+As(V), Organoarsenic: MMA+DMA.

840 The peak resolutions in Figure S2 are 1.35 to 1.40. In general, it is said that complete 841 separation is more than 1.5 : therefore, approximately $0.2 \%$ may be overlapping each other.

842

843

844

845

846

847 
875 Figure S3: Demonstration results of the rapid monitoring by the proposed method.

876 Injection interval time: $60 \mathrm{~s}$, Replication: 3, Monitoring time: $450 \mathrm{~s}$, Column: $\mathrm{C}_{18}$ ODS ACR 877 (particle size $5 \mu \mathrm{m}, 250 \mathrm{~mm}$ x ID $4.6 \mathrm{~mm}$ ), Eluent: $1 \mathrm{mmol} \mathrm{L}^{-1}$ diammonium hydrogen 878 phosphate (pH 2.0) $/ 0.05 \%$ methanol, (a) $1^{\text {st }}$ peak As(III)+As(V), $2^{\text {nd }}$ peak MMA+DMA at a 879 flow rate of $0.75 \mathrm{~mL} \mathrm{~min}^{-1}$, (b) $1^{\text {st }}$ peak $\mathrm{As}(\mathrm{III})+\mathrm{As}(\mathrm{V}), 2^{\text {nd }}$ peak MMA+DMA at a flow rate of $8801.0 \mathrm{~mL} \mathrm{~min}^{-1}$ (proposed condition), (c) $1^{\text {st }}$ peak TeMA, $2^{\text {nd }}$ peak $\operatorname{As}(\mathrm{III})+\mathrm{As}(\mathrm{V}), 3^{\text {rd }}$ peak $881 \mathrm{MMA}+\mathrm{DMA}$ at a flow rate of $1.0 \mathrm{~mL} \mathrm{~min}^{-1}$ (proposed condition).

882 